\title{
¿Evangelización o sacramentalización? Una reflexión crítica sobre la crisis sacramental de hoy
}

\author{
Orientador: Luiz Fernando Ribeiro Santana \\ Mestrando: Felipe Ortiz Dominguez \\ Área de Concentração: Teologia Sistemático-Pastoral
}

Linha de Pesquisa: Fé e Cultura

Amén de las definiciones que del hombre hacen las diversas disciplinas de la ciencia, descubrimos que, ante todo, el ser humano es un homo symbolicus y homo festivus o ludens. En la esfera celebrativa religiosa el hombre festeja, mediante una anamnesis, los momentos significativos del pasado; en un kairós, que no es cronológico, los acontecimientos del presente y, en una perspectiva escatológica, los deseos y anhelos del futuro. Estas celebraciones, por su carga subjetiva y en algunos casos de misterio, son imposibles de realizar sin el recurso a los símbolos. Así surgen en el mundo del cristianismo los sacramentos. Este trabajo de disertación tiene como finalidad apuntar la importancia de articular lo vivido cotidianamente con lo celebrado sacramentalmente y, en el caso del cristianismo, la exigencia a la referencia de la persona de Jesús de Nazaret y al proyecto del reino, por parte de quienes celebran los sacramentos. A partir de esta exigencia evangélica, se descubre la crisis sacramental experimentada en América Latina y que trato de exponer en este trabajo. Referenciados por el Concilio Vaticano II, específicamente por los documentos de la constitución dogmática Lumen Gentium sobre la iglesia, la constitución Sacrosanctum Concilium sobre la sagrada liturgia, y la constitución pastoral Gaudium et spes sobre la iglesia y el mundo de hoy, presento la importancia de rescatar la dimensión de la gracia salvífica de Dios para con los hombres, manifestada en los sacramentos y celebrados litúrgicamente en la asamblea. Este trabajo se suscribe en el ámbito de la antropología sacramental así como de la teología de los sacramentos, reuniendo elementos de eclesiología y liturgia presentando a los sacramentos como el lugar mistérico desde donde se revela y celebra la gracia del designio divino de salvación de Dios para con la humanidad.

Palavras-chave: Símbolo. Mito. Rito. 